\title{
CALGARY AREA BLUEBIRD TRAILS - 1982
}

\author{
DON STILES, 20 Lake Wapta Rise SE, Calgary, Alberta. T2J 2M9
}

This is the fourth year in which members of the Calgary Field Naturalists' Society have been monitoring Harold Pinel's Calgary Bluebird Trail. Since Harold Pinel's trail has been further modified each year with observers adding side loops and dropping House Sparrow-prone sections of trail, it was decided to group the Calgary area trails by direction from Calgary Southwest, Northwest and Northeast. This allows new sections to be added to trails without increasing the number of columns in the tables of results. This year three new sections of trail were added, two in the southwest and one in the northwest. This brings the total number of sections of trail to 13 with most observers handling from 15 to 55 houses. The exceptions are Blake Stillings with 312 houses and the northeast section (previously Andrew Stiles - Didsbury) with 119 houses. These two sections have been retained in the tables along with Nancy Murray's Seebe-Canmore section, so that these can be compared directly with previous years' results.

Statistics indicate that bluebird numbers were similar to last year with some sections up and others nearly equal or down. Several of the observers reported dead bluebird and Tree Swallow young in the nest. Young were usually of the same size, indicating an event such as a storm was the cause. Kay Morck reported 3 dead adult Tree Swallows in a single box west of Hartell on 1 June. This was after the heavy snow storm of 28 May, suggesting that they had starved or suffocated.

Vandalism was more severe than usual with 3 sections of trail being hit.
Linda Vanneste recorded 14 instances with 2 boxes stolen, 3 smashed, 2 shot up and 1 burned. Others were filled with rocks or beer cans. When Linda replaced a stolen box, it too was stolen and a note left thanking her for the box! Fortunately vandalism strikes only occasionally. Suggested solutions were public education and putting a logo and phone number on the boxes.

\section{Highlights}

Don Stiles reported a double brood of Tree Swallows in one nest that fledged 12 young (see Blue Jay, December 1982, 40(4):205). Betty Haines found four young bluebirds with no parents after the cat caught the male and the female disappeared. Blake Stillings placed the young with four others in a nestbox and all eight fledged.

One case of a grassland species of sparrow using a nest box was reported by Laurie Meijer-Drees who found 4 brown-speckled eggs in a bluebird-type nest on 30 May. The birds was seen only briefly; possible identification was Clay-colored Sparrow. No young hatched.

Blake Stillings reported an unsuccessful Boreal Chickadee nest. Nancy Murray found a Mountain Chickadee in one of her houses.

This is the second year of the Seebe Canmore trail. As in most trails more birds tend to find the houses in the second year. Bluebirds increased from 2 to 3 nests and Tree Swallows from 2 to 5. A large number of the 39 houses are unused due to the absence of grassland along the trail. 
Table 1. CALGARY AREA NESTBOX RESULTS - 1982.

\begin{tabular}{|c|c|c|c|c|c|c|}
\hline Trail & Southwest & $\begin{array}{l}\text { Blake } \\
\text { Stillings }\end{array}$ & Northwest & Northeast & $\begin{array}{l}\text { Seebe- } \\
\text { Canmore }\end{array}$ & Totals \\
\hline No. Boxes & 170 & 312 & 125 & 119 & 39 & 765 \\
\hline Miles of line & 111 & 140 & 84 & 65 & 21 & 421 \\
\hline \multicolumn{7}{|l|}{ Mountain Bluebird } \\
\hline No. Nests & 40 & 82 & 42 & 33 & 3 & 200 \\
\hline$\%$ Successful & 90 & 91 & 76 & 70 & 67 & 84 \\
\hline No. Eggs & 206 & 448 & 209 & 187 & 17 & 1067 \\
\hline \multicolumn{7}{|l|}{ No. Young } \\
\hline Fledged & 150 & 407 & 157 & 115 & 11 & 840 \\
\hline Clutch Size & 5.15 & 5.46 & 4.98 & 5.67 & 5.67 & 5.33 \\
\hline Y/Successful N & 4.17 & 5.43 & 4.90 & 5.0 & 5.5 & 5.0 \\
\hline Banded & 12 & & 50 & 74 & & 136 \\
\hline \multicolumn{7}{|l|}{ Tree Swallow } \\
\hline No. Nests & 114 & 205 & 83 & 70 & 5 & 477 \\
\hline$\%$ Successful & 90 & 92 & 83 & 76 & 60 & 87 \\
\hline No. Eggs & $540+$ & $1032+$ & 439 & 390 & 23 & $2424+$ \\
\hline \multicolumn{7}{|l|}{ No. Young } \\
\hline Fledged & $455+$ & 949 & 333 & 278 & 14 & $2029+$ \\
\hline Clutch Size & $4.74+$ & $5.03+$ & 5.23 & 5.57 & 4.6 & $5.08+$ \\
\hline Y/Successful N & $4.42+$ & 5.05 & 3.38 & 5.25 & 4.67 & $4.88+$ \\
\hline Banded & 18 & & 37 & 142 & & 197 \\
\hline House Sparrow & 4 & 14 & 5 & 18 & 1 & 42 \\
\hline House Wren & 7 & 1 & 2 & 6 & 0 & 16 \\
\hline Multiple Use & 6 & $7+$ & 10 & 18 & 1 & $42+$ \\
\hline Vandalism & 20 & 10 & $5+$ & 4 & 0 & 39 \\
\hline Boxes Not Used & 11 & 5 & 1 & 7 & 31 & 55 \\
\hline
\end{tabular}

George Blundun was attacked by adult bluebirds when he checked a nest with 5 young just ready to fledge.

Bob Krahulic reported a late Tree Swallow nest near Priddis. The first nest, already late, fell down when the young were feathered (late July). A second attempt fledged young about 26 August.

\section{House Sparrow Predation}

Blake Stillings mentioned two cases of persistent House Sparrows. Last year on the Horse Creek Road he removed House Sparrow nests three times from one box. This year he moved the box one-half mile to a side road. It still had House Sparrows, so he moved it again. There were Tree Swallows around and they used the box. About 10 days later there were 2 dead Tree Swallows in the nest, the victims of House Sparrow predation. In the second case west of Cremona two houses near each other had bluebirds in one and sparrows in the other. When the House Sparrow box was removed they took over the bluebird nest.

Don Stiles noted an area with dead adult bluebirds and swallows in the nests with heads pecked, an obvious sign of House Sparrow predation. It was first noticed in that area last year although the previous 4 years there had been no House Sparrows.

The use of plexiglass roofs which let light in is supposed to discourage sparrows. Six houses with 2" $x$ 3" squares of plexiglass in the roof were placed on the sparrow-prone section of the East Didsbury section of trail. Two were still used by House Sparrows. A similar experiment with $2.5^{\prime \prime}$ circles 


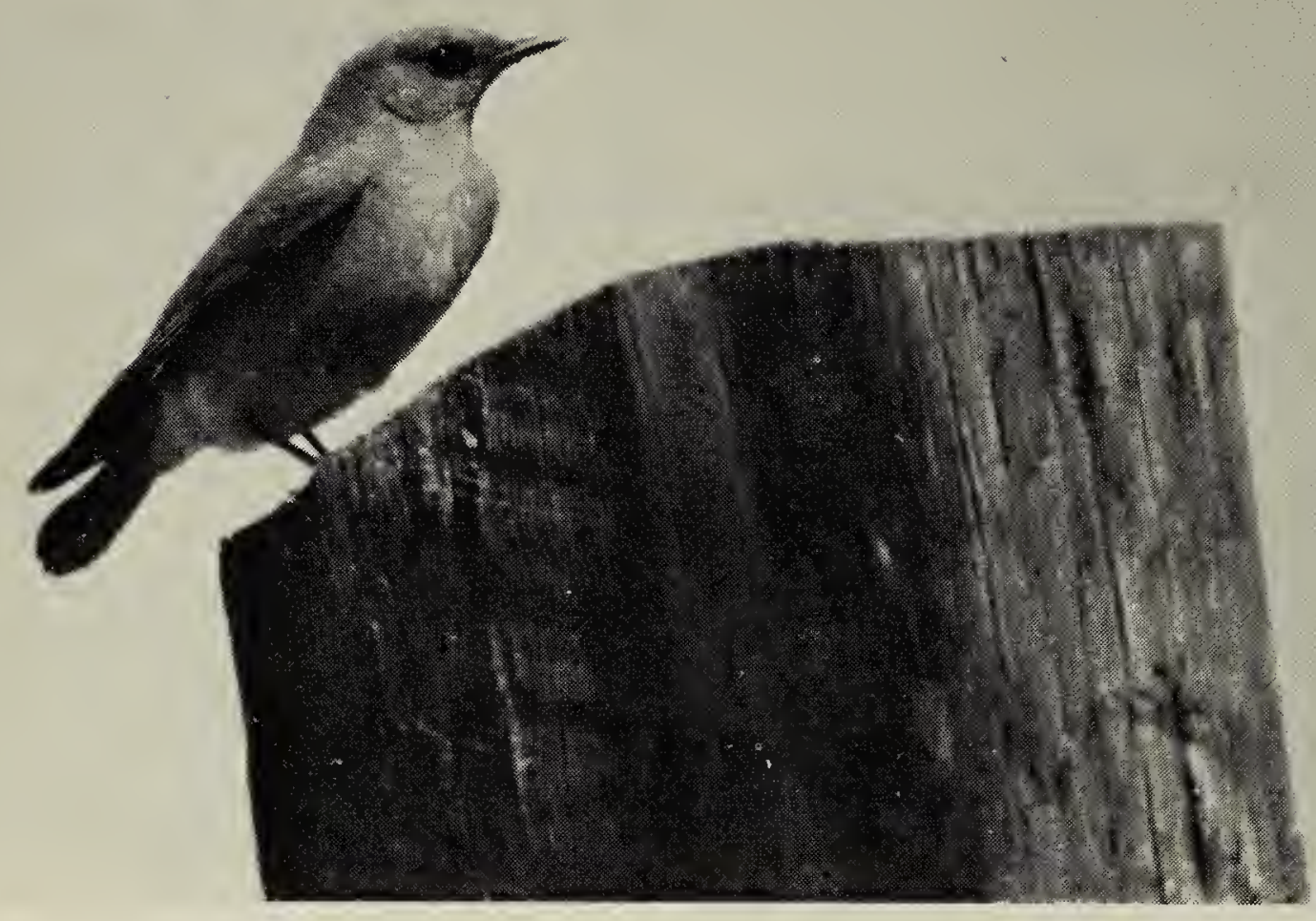

Mountain Bluebird.

Juhachi Asai

produced similar results - some House Sparrows still used the boxes. Further experimentation will be done using roofs entirely of plexiglass.

Don Grussing of Minnesota stated in his book "How to Control House Sparrows" (published by Roseville Publishing House, P.O. Box 8083,
Roseville, Minnesota 55113) that the male has more attachment to his territory than even to his mate. He will stick with a house he has chosen even if he loses his mate, and waits for another female. This suggests that houses infested with House Sparrows must be completely removed from the territory.

Table 2. RESULTS OF LATE MONITORING

\section{Species}

Tree Swallow

Mountain Bluebird

House Wren

House Sparrow

Unused

Total

$\begin{array}{cr}\text { Active } & \begin{array}{r}\text { Young Fled } \\ \text { Inactive }\end{array} \\ 10 & 43 \\ 3 & 14 \\ 2 & 2 \\ 2 & 3 \\ 17 & 62\end{array}$




\begin{tabular}{lccccccc} 
& \multicolumn{3}{c}{ Mountain } & Bluebirds & \multicolumn{3}{c}{ Tree Swallows } \\
& No. Nests & Total & & \multicolumn{2}{c}{ No. Nests } & Total \\
with Eggs & Nests & $\%$ & & with Eggs & Nests & $\%$ \\
Date & 1 & 19 & 5.3 & 14 & 77 & 18.2 \\
1979 - 30 June, 1 July & 2 & 30 & 6.7 & 15 & 69 & 21.7 \\
1980 - 29 June & 5 & 32 & 15.6 & 15 & 68 & 22.1 \\
1981 - 28 June & 3 & 33 & 9.1 & 8 & 70 & 11.4 \\
1982 - 1 July & 11 & 114 & 9.6 & 52 & 284 & 18.3 \\
Total & & & & & & &
\end{tabular}

\section{Late Monitoring}

Other years our last monitoring about the first week in July recorded late bluebird and swallow nests with only eggs in them. This year Dan Cloutier and his sister Carmen monitored 88 houses on the East Didsbury trail on 18 and 20 July. Three nests had dead Tree Swallow young and one had a dead adult bluebird. Other results are in Table 2.

Dan also cleaned inactive nests at this time. Although there is a strong ammonia smell in the nest just after fledging, making this an unpleasant task, cleaning them at this time will shorten the time for the final check before next year's nesting season.

Table 3 compares late nesting in the last four years. These figures give a rough idea of the percentage of nests for which results could be recorded by late monitoring.

\section{Banding}

Banding efforts were increased this year with Don and Philip Stiles on the East Didsbury trail, Ray Woods in the Elkton area, Laurie Meijer-Drees on the Sundre loop and Don Stiles west of Dewinton. Final totals were 136 Mountain Bluebirds and 236 Tree Swallows banded.
Band recoveries were up over last year. Of interest were two Tree Swallows banded by Harold Pinel in 1977 in the East Didsbury trail, Ray Woods in the recaptured previously as follows:

880-98835 - Banded as an adult, 1977, in house H179. Recaptured 19803 mi nne in A8. Recovered 13 June $19826.5 \mathrm{mi} e$ in A37A dead due to sparrow predation. This bird was at least 6 years old.

850-98849 - Banded as a young in H390. Recaptured $19789 \mathrm{mi}$ ne in A71. Recaptured $19792 \mathrm{mi} \mathrm{s}$ in A143. Recaptured 1 July 19822.5 mi ese in A-S1. This bird is still active at 5 years age and with its mate fledged 4 young this season.

In addition 4 Tree Swallows banded in 1981 were recaptured. Three were banded as adults and were recovered 1 $\mathrm{mi}, 3 \mathrm{mi}$ and $0.5 \mathrm{mi}$ from their banding sites. The fourth band was from a young banded 2 mi from the box in which the band was found. There was no trace of the bird and the band was in the bottom of the box. House Sparrow predation is assumed. The 3 adults were among 26 banded in 1981 for a $11.5 \%$ recovery; the single young was one of 69 young banded for a $1.4 \%$ recovery.

Finally one female bluebird banded in 1981 was found dead in the same box that she nested in last year. 